\title{
Huge carbohydrate assimilates delay response to complete defoliation stress in oil palm (Elaeis guineensis Jacq.)
}

\author{
Walter Ajambang ${ }^{1,2}$, Sintho W Ardie ${ }^{1}$, Hugo Volkaert ${ }^{3}$, Madi Galdima ${ }^{2}$ and S. Sudarsono ${ }^{1 *}$ \\ ${ }^{1}$ Department of Agronomy and Horticulture, Bogor Agricultural University, Indonesia \\ ${ }^{2}$ Institute of Agricultural Research for Development, Cameroon \\ ${ }^{3}$ Centre for Agricultural Biotechnology, Kasetsart University, Thailand
}

\begin{abstract}
Understanding how and when crops cope with and respond to stress during reproductive development may be able to forecast total crop production under abrupt climate change. We studied the effect of complete defoliation under time-specific climate-related conditions on inflorescence sex differentiation in oil palm. A total of 162 pisifera oil palm trees were completely defoliated at the rate of three trees per month between July 2007 and December 2011. Complete defoliation significantly increased male inflorescence induction by $104 \%$ when compared with control without defoliation. Acute soil water deficit (SWD) of $16.8 \mathrm{~mm}$ between the 30th and $60^{\text {th }}$ day after complete defoliation (DAD) had an additional positive effect on male inflorescence production. A regression analysis on 18 time-specific, climate-related research and two inflorescence-related variables resulted in high regression coefficients for the time period $30^{\text {th }}$ to $60^{\text {th }} \mathrm{DAD}$. This is an indication that oil palm responds to complete defoliation stress after a 30-day delaying period. Total soluble sugars measured at 45 DAD showed a depletion of $55 \%$ in the leaves and $21 \%$ in inflorescence of defoliated trees compared to control trees without defoliation. Preferential sex differentiation in oil palm towards maleness is an acclimation response to the depletion of total soluble sugar inflected by mechanical and soil water deficit stresses. These results shall permit the simulation of male inflorescence induction and yield forecasting in other geographical locations.
\end{abstract}

Key words: Fruit bunches, Male inflorescence induction, Mechanical stress, Sugar depletion, Sex differentiation, Stress responses

\section{Introduction}

Abiotic stresses such as drought, flood, extreme temperatures, chemical toxicity and oxidative stress are serious threats to plants. All forms of stress usually have a negative impact on plant assimilates, which are primarily made up of carbohydrates and are used for plant growth and development. Therefore, their abundance or depletion may regulate plant gene expression (Ohto et al., 2001; Lee et al., 2010). It is known that carbohydrate regulated genes play important roles in responding to changing environments (Koch, 1996; Sheen et al., 1999; Smeekens, 2000; Liu et al., 2013).

Received 02 September, 2014; Revised 12 October, 2014; Accepted 17 October 2014; Published Online 06 January 2015

*Corresponding Author

S. Sudarsono

Department of Agronomy and Horticulture, Bogor Agricultural University, Indonesia

Email: s_sudarsono@ymail.com
Carbohydrate depletion enhances expression of genes associated with photosynthesis, reserve mobilization and export (Koch and Zeng, 2002; Rolland et al., 2002). Carbohydrates have also been associated with plant cell and organ differentiations (Gibson, 2000; Eastmond and Graham, 2001; Lopez-Molina et al., 2001; Pien et al., 2001). Sugar pulses to apical meristem can lead to meristem differentiation through cell division. High sugar levels reduce photoperiod effects on floral evocation (Corbesier et al., 1998; Roldan et al., 1999) or even completely replace it. The later has been observed in Lolium temulentum L. The changes response was associatted with upregulation of invertase genes at the apical meristem (King, 1991). Evidence has also been provided that a decrease in assimilates supply due to defoliation or shading, increases early fruit abscission in evergreen trees (Gomez-Cadenas et al., 2000). Hartwig et al. (2011) reported that the phytohormones brassinosteroids (BR) regulate abiotic 
stress responses and control sex differentiation in maize.

Fresh Fruit Bunches (FFBs) in oil palm are fertilized female inflorescences that have developed into mature fruits. The FFB development requires much more energy than the male inflorescences. Production of FFB mobilizes much primary photosynthate and or carbohydrate reserves. Under certain conditions, such reserve mobilization may alter the inflorescence sex ratio and FFB production in the next season (Nouy et al., 1999). Hardon and Corley (1976) reported that oil palm would produce predominantly male inflorescences after suffering serious loss of carbohydrate through previous year's harvests. Campbell et al. (2012) showed that alternating precipitation cycle could affect flowering phenology; inducing male biased floral sex ratio in Cucurbita pepo.

Development of male inflorescences does not require much energy compared to the female ones because they only produce pollen, which falls off two weeks after anthesis. The whole inflorescence quickly senesce. Hence the male inflorecence development does not require carbohydrate reserve mobilization and more photosynthate is conserved when oil palm produces principally male inflorescences. Subsequently, increase in carbohydrate reserve results in the production of predominantly female inflorescences from the oil palm trees in the following season.

Oil palm producing the pisifera fruit type is used as male parent in breeding and seed production programs. However, the pisifera is very feminine under normal plantation conditions. The female inflorescences of pisifera do not develop into mature fruits since they are aborted. Thus FFB is not produced in pisifera, resulting in accumulation of reserve carbohydrate. Subsequently, such conditions lead to continual evocation of female inflorescences and the absence of male ones. This is undesirable condition for pisifera in oil palm breeding and seed production since there will be less pollen provider (DurandGasselin et al., 1999).

Inflorescence evocation and sex differentiation in oil palm is regulated by soil water availability (Caliman and Southworth, 1998), carbohydrate depletion (Hardon and Corley, 1976) and severe leaf pruning (Corley and Tinker, 2003). DurandGasselin et al. (1999) employed removal by pruning of all the fronds and leaving only the middle un-opened one (complete defoliation stress) of oil palm to evoke male inflorescences. The complete defoliation stress treatment may alter the balance of sugar in the treated oil palm, leading to the evocation of male inflorescences (Campbell et al., 2012).

Durand-Gasselin et al. (1999) suggested that the effects of severe defoliation stress treatment on male inflorescence evocations are probably immediate. However, the exact moment for which the oil palm initiates male inflorescence formation in response to stresses is not yet known. On the other hand, a number of researchers (Gray, 1969; Corley, 1976; Killmann and Lim, 1987; Henson et al. 1999; Legros et al. 2009; Cros et al. 2013) reported that the oil palm trunk contains large reserves of carbohydrates. These carbohydrate reserves may serve as a buffer during transitory periods of source-sink imbalances caused by a halt in photosynthetic activities. Thus, the large reserves in oil palm trunk will be used to absorb any shock arising from stress within a certain time limit. When the reserves are considerably depleted, the plant would initiate the response mechanisms through gene expression. Under abiotic stress, such as drought stress, plants tend to mobilize carbohydrate reserves. Therefore, it is expected that oil palm will mobilize some of the carbohydrate reserves stored in the trunk to response to the stress. Such response is acclimation in the form of male inflorescence induction. Moreover, abiotic stress responses have also affect sex differentiation. Association among abiotic stress responses and sex differentiation has been demonstrated in maize by Hartwig et al. (2011). Therefore, combining complete defoliation and water stresses may positivally affect male flower induction in oil palm.

In oil palm, the inflorescences were initiated approximately at 18-26 months before ones' visually observed them. Therefore, understanding the factors affecting and the periods of male inflorescence induction in oil palm would be interesting. Knowledge on the period of oil palm initiates response to complete defoliation stress through the expression of genes would be very interesting to molecular scientists. This knowledge is important because the expressed genes during complete defoliation stress might be the same genes involve in male inflorescence induction. Moreover, such knowledge may help us to effectively plan and produce pollen from the limited number of pisifera type of oil palm growing under current unstable climatic conditions. However, there is only limited information available about the required parameters, which will guide breeders and seed producers to efficiently induce male inflorescences from pisifera or simulate FFB production under such condition, especially in this era of climate instability. 
The objectives of this research were to evaluate the effects of different time-specific climatic parameters on male inflorescence evocation in completely defoliated oil palm and to estimate the moment of response initiation to the stress. Understanding the factors affecting male inflorescence evocation and the moment of response by oil palm may provide molecular scientist the ability for studying gene expression, accurately isolating and identifying genes responsible for sex determination and oil palm crop production.

\section{Materials and Methods \\ Experimental site}

Complete defoliation and data collection were conducted from July 2007 until May 2013 at the Specialized Centre for Oil Palm Research La Dibamba Douala in Cameroon $\left(3.948848^{\circ} \mathrm{N}\right.$ $\left.9.762726^{\circ} \mathrm{E}\right)$. The rainy season for La Dibamba lasts from March to October with limited precipitation during the 4 to 5 months dry season. Mean annual temperature between 2007 until 2013 was $28.1{ }^{\circ} \mathrm{C}$ and the average annual precipitation was $2,769 \mathrm{~mm}$ of rainfall for the period of this research. The soils are classified as ferralsols with clay accumulations and low base saturation. The pisifera were planted in 1993 to serve as male parents and pollen provider in breeding and seed production programs respectively.

\section{Complete defoliation treatments}

The complete defoliation treatment consisted of the removal by pruning of all the leaves and preserving only the middle un-opened one so as to avoid tree death. This activity consisted of removing all the leaves of three trees each month during the year. Pruning of the trees began in July 2007 until end of December 2011 and observations of male inflorescence formation were done until May 2013. The total number of trees pruned during the rainy seasons was equal to the total number of trees pruned during the dry seasons.

\section{Total soluble sugar}

A sub sample of six trees was used for total soluble sugar analysis. The treatment consisted of complete removal of leaves from the palm as described by Durand-Gasselin et al. (1999) while the control consisted of non-defoliated trees. Both treatment and control were each replicated three times thus, three trees were completely defoliated and the remaining three serving as control were not defoliated. All six trees were cut down and dissected 45 days after complete defoliation (DAD) for tissue extraction. The 45 DAD was chosen for tissue extraction because it is mid-way between the 30th and 60th day after complete defoliation treatment; and was retained based on the results from regression analysis on estimating the time for response initiation to complete defoliation stress. The soluble sugar analysis was to evaluate how far the energy sink had been depleted. The samples for sugar quantification were made up of young inflorescence tissues extracted at the axil of leaf number +5 and leaf tissues extracted on young tender un-emitted leaf. The leaf numbers were obtained by counting from leaf number 0 which is represented by the middle un-opened leaf. Leaf number +1 was obtained by counting outwards in the left direction from leaf number 0. Leaf number 1 was obtained by counting inwards towards the right direction from leaf number 0 . This was done for all the replicates and a total of 12 tissues were collected. Total soluble sugar in $\mu \mathrm{g} \mathrm{g}^{-1}$ of dry matter (DM) was measured at the Laboratory of Plant Physiology Bogor Agricultural University using $5 \mathrm{~mL}$ of $80 \%$ hot ethanol (Chow and Landhausser, 2014).

\section{Observations}

Total number of inflorescences emitted was recorded in the field prior to inflorescence isolation. Inflorescences were harvested at the stage of anthesis approximately 2 weeks after isolation and taken to the laboratory for pollen viability test and pollen conditioning. The corresponding number of inflorescences produced when rainfall, soil water deficit (SWD) and number of rainy days were measured at 10, 20, 30 and 60 DAD, were recorded. Measurements continued throughout the year but analysis was done until 60 DAD for each tree as guided by literature (Killmann and Lim, 1987; Durand-Gasselin et al., 1999; Henson et al., 1999; Cros et al., 2013). The corresponding number of inflorescences produced by trees was recorded between the 10th and 36th month after treatment. This is the time period for which the treatment has an effect on the plants because the tree would complete its inflorescence production cycle every 36 months (Hartley, 1988; Durand-Gasselin et al., 1999). We used this data to estimate how rainfall, SWD and number of rainy days at 10, 20, 30 and 60 DAD would influence total number of male inflorescences emitted. This estimation was done to find out the period at which male inflorescence induction or sex differentiation occurred. These climatic data were measured for each series of treatments that were carried out at the rate of 03 trees each month. 
Climatic data were recorded thrice daily for the whole period of the trial. The SWD was estimated using the equation; $\mathrm{SWD}=(\mathrm{PE}-(\mathrm{IR}+\mathrm{P}))$. Where, $\mathrm{IR}=$ initial water reserve, $\mathrm{P}=$ monthly precipitation, $\mathrm{PE}=$ potential evapotranspiration. Potential evapotranspiration was calculated according to FAO guidelines for computing crop water requirements (Allen et al., 1998).

A total of eighteen climate-related research variables and two inflorescence-related response variables were studied. The climate related variables were analyzed for a period of three months following each treatment and included among others; precipitation 10 days after complete defoliation $(0-10 \mathrm{~mm}) \mathrm{DAD}, 20(0-20 \mathrm{~mm}) \mathrm{DAD}$, $30(0-30 \mathrm{~mm})$ DAD and $60(0-60 \mathrm{~mm})$ DAD. Precipitation between day 10 and day 20 (10-20 $\mathrm{mm})$ DAD; between day 20 and day $30(20-30 \mathrm{~mm})$ DAD and between day 30 and day $60(30-60 \mathrm{~mm})$ DAD were also recorded. The same measurements were also taken for number of rainy days (RD) and SWD after complete defoliation. The total number of male inflorescences produced before complete defoliation (FBD) and the total number of male inflorescences produced after complete defoliation (FAD) was recorded.

\section{Statistical analysis}

Analysis of data was carried out using the software SAS version 9.3 (SAS Institute Inc, Cary NC). The sum, averages and standard deviations were calculated for all the observations and they were used for subsequent analysis. A Pearson's regression analysis was carried out to study how increasing or decreasing levels of experimental variables (heights of rainfall, soil water and number of rainy days) would affect responses (total number of male inflorescences produced). A paired T- test was used to compare the effects on the same individuals before and after treatment. A two sample $\mathrm{T}$ - test was used to compare response from averages of two different sets of data. All tests were measured at a confidence interval of $95 \%$.

\section{Results and Discussions Precipitation and soil water deficit at research site}

Climatic data was analyzed for the period between 2007 and 2013 at La Dibamba Research Centre. The average monthly SWD curve and monthly precipitation bars developed from recorded data are given in Figure 1. We observe that the peak of the rainy season is between the months of
August and September. There is a highly significant difference in soil water deficit between the different months of the year. Soil water deficit is at $0 \mathrm{~mm}$ between July and November while it ranges from 0.1 to $120 \mathrm{~mm}$ in the rest of the year.

\section{Effect of complete defoliation on male inflorescence induction}

Figure 2 shows a male inflorescence and the different activities leading to its induction. It illustrates a mature pisifera palm in its nondefoliated form, a defoliated and a recovering pisifera 45 DAD. Figure 3 shows male inflorescence production and average annual precipitation records six years before complete defoliation treatment and six years after treatment. Precipitation was recorded between 2001 and 2012. It was observed that mean annual precipitation pattern in the period between 2001 and 2006 was similar to that observed between 2007 and 2012. Although the mean annual precipitation curve was similar between the two periods, male inflorescence production experienced a sharp increase between 2007 and 2012 as compared to that of the period between 2001 and 2006. The interval from 2007 to 2012 is the period when complete defoliation was carried out on the same individuals as those represented in the period between 2001 and 2006. An increase of $104.25 \%$ in total number of male inflorescences was observed in the period between 2007 and 2013. This was as an effect of complete defoliation treatment on the trees. A paired $\mathrm{T}$ - test was carried out and it was observed that there was a significant effect on total male inflorescence production after complete defoliation $(\mathrm{M}=7.12$, $\mathrm{SD}=4.09)$ than that before complete defoliation $(\mathrm{M}=3.48, \mathrm{SD}=3.47), \mathrm{t}(41)=5.99, \mathrm{p}<0.000$. This is an indication that preferential sex differentiation in oil palm is a method of response and acclimation to mechanical and abiotic stress.

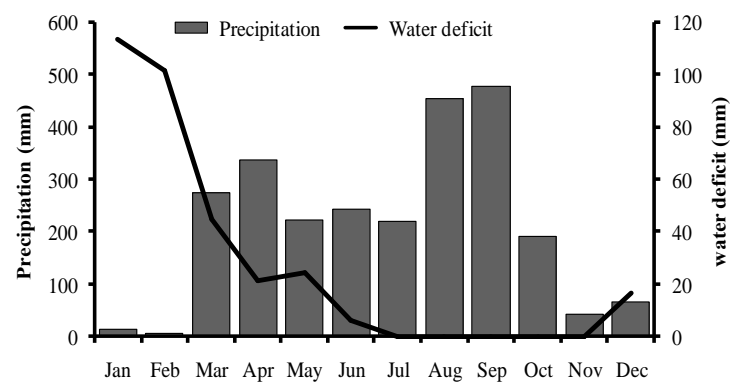

Figure 1. Monthly soil water deficit (curve) and monthly precipitation (bars) as recorded at the La Dibamba Meteorological Station during the period of research. 

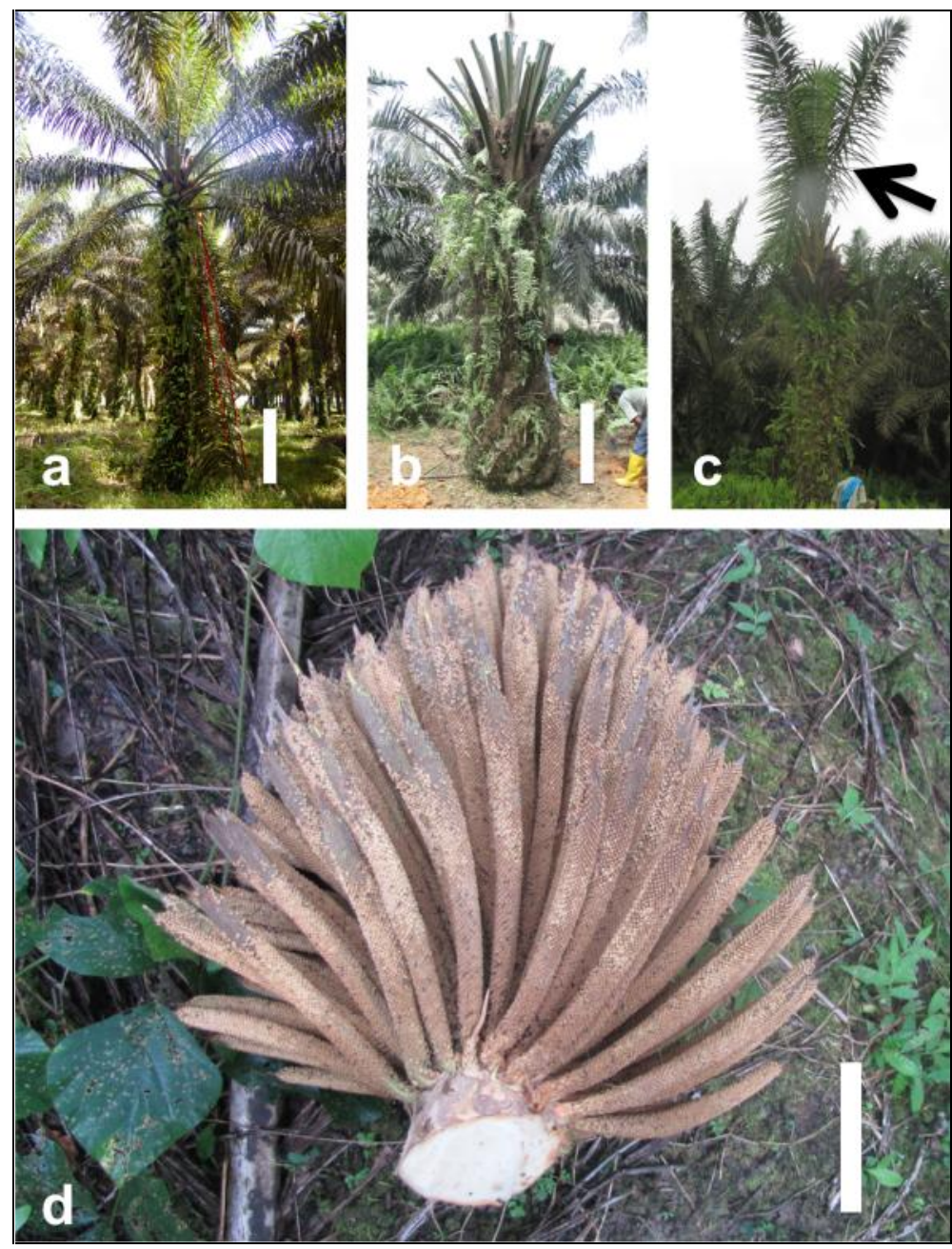

Figure 2. A male flower induced from complete defoliation (a) mature non defoliated pisifera palm (b) completely defoliated pisifera palm (c) a recovering pisifera palm 45 DAD (d) a mature male inflorescence at anthesis. The white bars on (a) and (b) are drawn to $1 \mathrm{~m}$ scale while that of $\mathrm{d}$ is $10 \mathrm{~cm}$ scale. Arrow points to newly developed oil palm leaves.

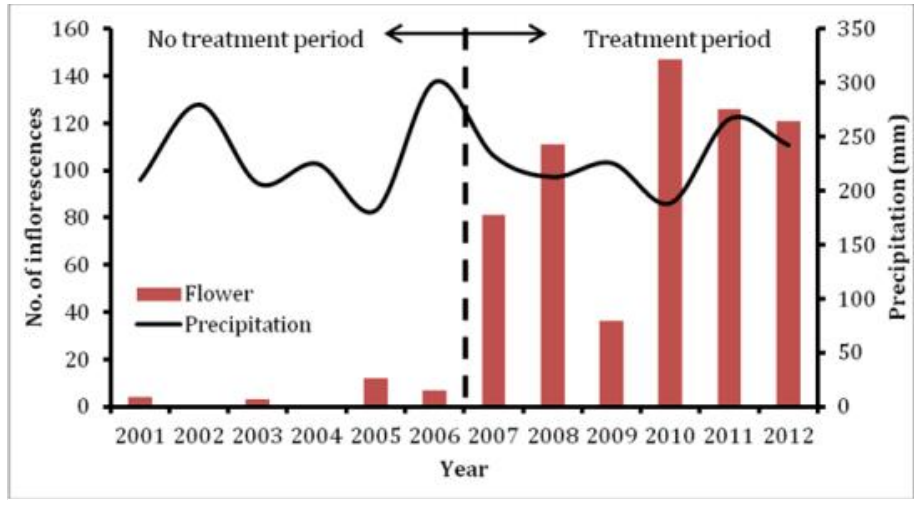

Figure 3. Male inflorescence production and mean annual precipitation between 2001 and 2012 at La Dibamba before and after treatment. The broken line between year 2006 and 2007 represents the start of defoliation treatment. The number of male inflorescences produced is represented by bars corresponding to the primary vertical axis while precipitation curve is represented by the secondary vertical axis. 
In oil palm, the female inflorescences develop into the fruits and the developing bunches are very demanding in terms of energy especially between the stages of inflorescence emission and fruit maturity. Energy is needed in embryo, endosperm and fruit development. A single fresh bunch weighs an average of $20 \mathrm{Kg}$ and a single oil palm tree bears and carries between 15 and 25 bunches each year. Each female inflorescence requires between 5 to 6 months on the tree to get to fruit maturity (Corley, 1976; Durand-Gasselin et al., 1999; Corley and Tinker, 2003). In contrast, the male inflorescence has an average weight of just $2 \mathrm{~kg}$ and does not remain for a long period on the palm tree, progressing to senescence in about one month after anthesis, and liberating the oil palm tree from further energy demand. Therefore the production of more male inflorescences in response to stress created by complete defoliation is a strategy developed by the oil palm to conserve limited resources for maintenance. This acclimation was thus in form of male inflorescence induction in expense of female one (Hardon and Corley, 1976; Campbell et al., 2012).

\section{Relationship of climatic parameters and male inflorescence production}

Amount of daily precipitation and number of rainy days were analyzed for a period of two months after defoliation. It should be noted the impact of complete defoliation on the oil palm trees reduce significantly after two months because the trees would have produced about five open leaves that can produce carbohydrate through photosynthesis. The graphs presented in Figure 4 show that the number of male inflorescences reduced with higher quantities of precipitation; while Figure 5 show a downward trend for number of male inflorescences induced as against increasing number of rainy days. The trend is similar to that of total precipitation because of the ferralsols soil type, which retains water because of clay accumulations. Several researchers have evoked the relationship between soil water availability and inflorescence sex determination (Spalik 1991; Bikel and Freeman, 1993; Campbell et al., 2012).

\section{Period for switching on sex differentiation in response to defoliation}

A test was carried out to determine the period in which the oil palm tree will initiate response mechanisms to the shock received from complete defoliation stress. The test was done on the specified time intervals resulting in 18 associated climate parameters considered as explanatory variables and two male inflorescence emissions considered as dependent variable. A regression analysis carried out on these 18 variables revealed that those climatic variables associated with the second month after complete defoliation had the highest influences on male inflorescence production with R2 $=15.6 \%$ for precipitation recorded between the 30th and 60th day after treatment, $22.1 \%$ for the total number of rainy days recorded between the 30th and 60th day after treatment and $12.7 \%$ for precipitation recorded 60 days after treatment. These variables and their correlations are shown on Table 1 . The other 15 variables each had an R2 close to zero and these are variables associated with the first 10, 20 and 30 days after complete defoliation respectively. It should be noted that other variables such as genetic, physiological and farm management do influence inflorescence induction and represent the other part of correlations that are not measured in this study.

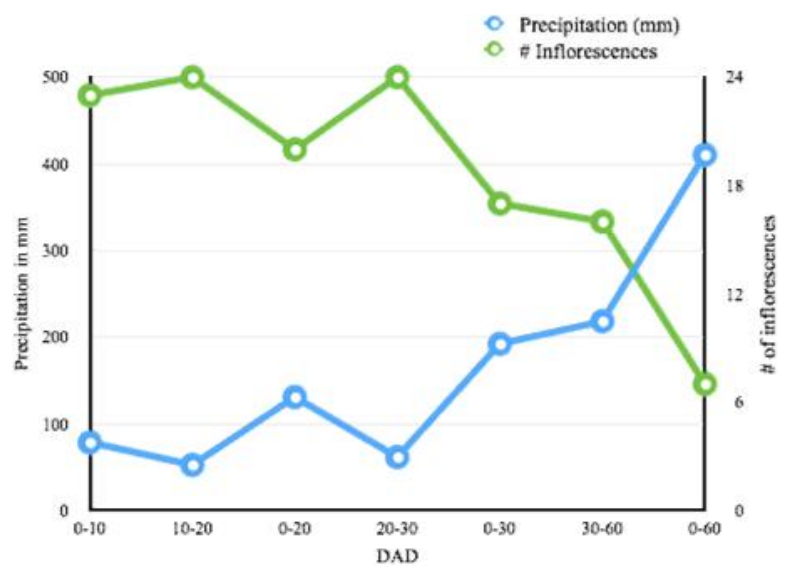

Figure 4. The relationship between amount of precipitation in the first two months after complete defoliation and number of male inflorescence induction in pisifera oil palm.

There was a significant relationship observed between the number of male inflorescences produced and three related soil water availability variables. These variables are the amount of precipitation that was registered in the second month, the number of rainy days registered in the second month and the total amount of precipitation registered during the first two months after complete defoliation. These variables, which are environmental data collected during the second 30 days after complete defoliation gives us a clue on when the oil palm senses the impact of complete 
defoliation and then responses to it. The correlation coefficients presented in Table 1 do not some up to 1 because flowering in oil palm is not only influenced by environmental factors; but also by genetic factors and physiological status of the trees (Adam et al., 2005).

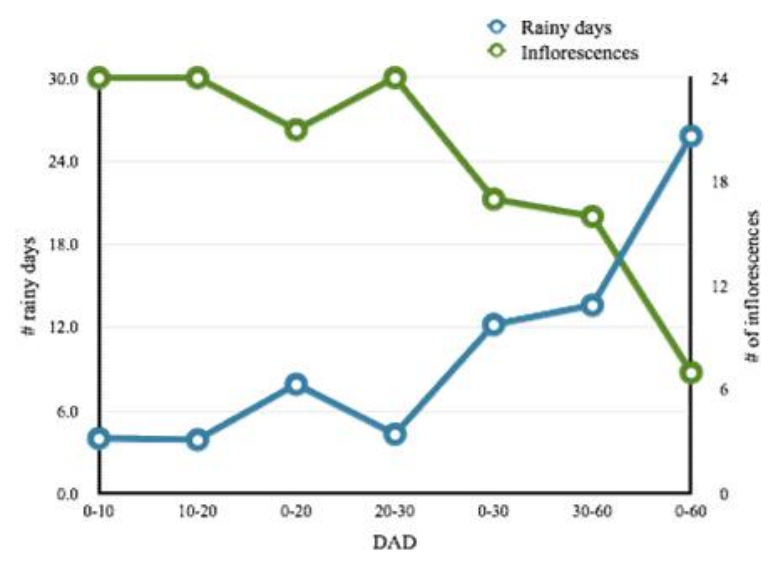

Figure 5. The relationship between number of rainy days in the first two months after complete defoliation and number of male inflorescence induction on pisifera oil palm.

The oil palm is a perennial with a rich rooting system and a very large trunk accumulating more than $65 \%$ of carbohydrate reserves (Legros et al., 2006, 2009). It would take several days for the oil palm to sense the stress impact and this occurs only when the carbohydrate reserves in its trunk are highly depleted. The trunk is considered as the most likely site for carbon reserve (Henson et al., 1999) and also contains a high proportion of parenchymatous ground tissue (Killmann and Lim, 1987). The oil palm trunk has been shown to contain high proportions of water soluble and acid hydrolysable carbohydrates (Gray, 1969) which were sufficient to sustain bunch production for a significant period after photosynthetic activity was drastically reduced by severe leaf pruning (Corley, 1976). Henson et al. (1999) measured total soluble sugar in oil palm trunk and found it contained between $54.3 \%$ and $81.9 \%$ of soluble sugars. In closely related trees to the oil palm such as Cocos nucifera (Mialet-Serra et al. 2008; Silpi et al. 2007) and in the sago palm (Flach and Schuiling, 1989), the large and variable reserve compartment for carbohydrate is located in the trunk and it occasionally serves as a buffer for transitory source-sink imbalances (Mialet-Serra et al., 2008). The trunk of an 8 year old sago palm contains $93 \mathrm{~kg}$ of stored carbohydrates while that of a similar oil palm trunk contains $37 \mathrm{~kg}$ (Henson et al., 1999) up to $47.9 \mathrm{~kg}$ of carbohydrate (Corley, 1976). Hence, it is logical for the oil palm to start responding to complete defoliation only after depletion of a considerable amount of the reserve carbohydrates. This means that in this experiment, the oil palm switches on its response mechanism between day 30 and day 60 after it was completely defoliated, as suggested by the data.

\section{Total soluble sugar in leaf and inflorescence tissues}

Figure 6 shows the different stages leading to the extraction for tissues used in total soluble sugar analysis. Both the leaf and inflorescence tissues were obtained following the dissection the tree crown. Total soluble sugar was reduced by $55 \%$ in leaves and $21 \%$ in inflorescences on completely defoliated plants as compared to un-defoliated plants 45 DAD. Figure 7 shows the amount of total soluble sugar measured on leaves and inflorescences 45 DAD between completely defoliated plants and the control un-defoliated ones. The period of 45 DAD was chosen based on the previous findings of this present study.

The depletion of total soluble sugar on severely defoliated plants by $55 \%$ on leaf tissues and $21 \%$ on flower tissues at 45 DAP, may have been an indication that the plants are already in a critical state and thus may have to acclimate in order to maintain survival. This acclimation was thus in the form of male inflorescence induction in expense of female inflorescence (Hardon and Corley, 1976; Campbell et al., 2012).

Table 1. Correlation coefficients for selected variables that had a significant relationship with male inflorescence number.

\begin{tabular}{llll}
\hline Variable & $(30-60 \mathrm{~mm}) \mathrm{DAD}$ & $(30-60 \mathrm{rd}) \mathrm{DAD}$ & $(0-60 \mathrm{~mm}) \mathrm{DAD}$ \\
\hline Mean & 218.29 & 13.60 & 410.40 \\
Correlation & $\mathrm{R}=-0.395$ & $\mathrm{R}=-0.470$ & $\mathrm{R}=-0.316$ \\
& $\mathrm{R}^{2}=0.156$ & $\mathrm{R}^{2}=0.221$ & $\mathrm{R}^{2}=0.127$ \\
Probability & $\mathrm{p}<0.01$ & $\mathrm{p}<0.001$ & $\mathrm{p}<0.05$ \\
\hline
\end{tabular}

(30-60 mm) DAD = Amount of precipitation registered between the 30th and the 60th day. (30-60 rd) DAD = Number of rainy days registered between the 30 th and the 60 th day; $(0-60 \mathrm{~mm}) \mathrm{DAD}=$ cumulative precipitation registered during the first two months after pruning. 

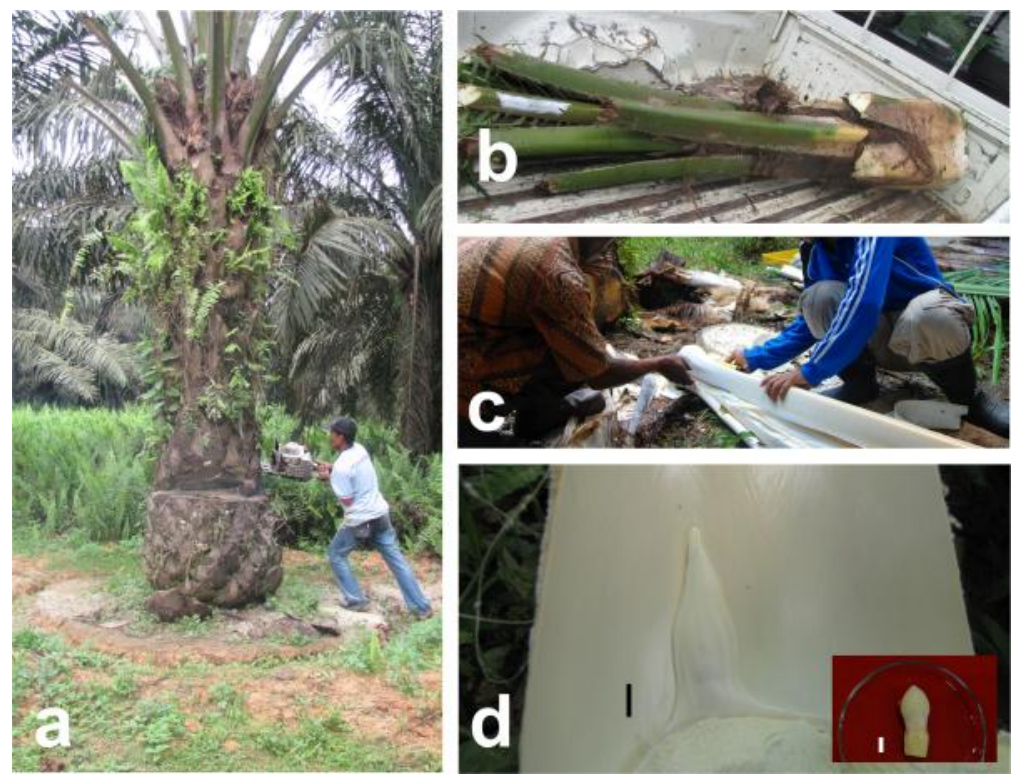

Figure 6. Stages leading to tissue extraction for total soluble sugar analysis. (a) a mature pisifera being felled 45 DAD, (b) transportation of the reduced crown to the laboratory for tissue extraction, (c) leaf and inflorescence extraction (d) inflorescence located at leaf axil +5 (on red background) placed on the leaf petiole.

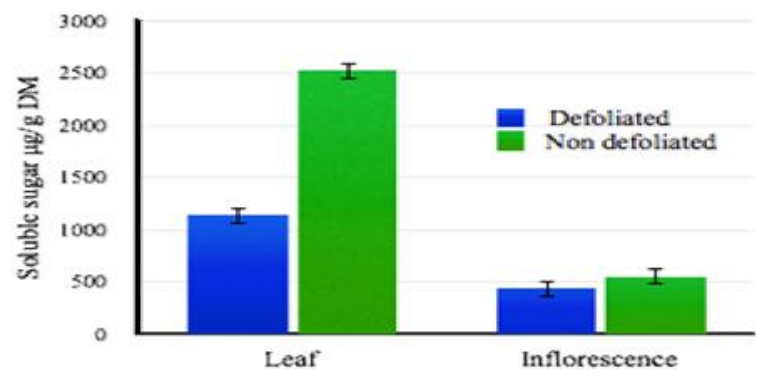

Figure 7. Total soluble sugar content in inflorescences and leaves from non defoliated (control) plants and previously defoliated plants 45 days after defoliation.

We have seen from earlier works that the oil palm has enough energy to absorb immediate shock from carbohydrate depletion caused by a sudden halt in its photosynthetic process. It is also known that the oil palm produces between two and three leaves every month (Hardon and Corley, 1976; Adam et al., 2011). Therefore enough leaves would have been produced after two months of complete defoliation stress treatment to be able to reverse the effects of complete defoliation stress on oil palm. Estimating the time period on when response mechanisms are initiated against a particular stress, gives us an indication on when genes responsible for the stress regulation are expressed in the plant. We know that the transcription of these regulatory genes is time and site specific. For further genetic and molecular studies where tissue extraction and RNA isolation are needed, it would be very important to know when and where to extract tissue for the studies because regulatory genes may be temporally and spatially expressed and the mRNA may be degraded rapidly.

\section{Effect of increasing soil water deficit on male inflorescence production}

We showed in Figure 3 that complete defoliation as a single factor, increased male inflorescence induction at field capacity. Increasing values of SWD measured during the second month after defoliation was tested against male inflorescence production (Figure 8). There was a sharp increase in the number of male inflorescences produced when SWD increased from field capacity to $16.8 \mathrm{~mm}$. Then there was a decreasing trend of inflorescence production as SWD increased to $146.2 \mathrm{~mm}$. Also, a two sample T-test at 95\% confidence interval assuming equal variance confirmed that a significant higher number of male inflorescences were produced when complete defoliation was done during the dry periods $(\mathrm{M}=$ $7.03, \mathrm{SD}=4.387)$ than that when at field capacity $(\mathrm{M}=4.88, \mathrm{SD}=2.790), \mathrm{t}(57)=2.16, \mathrm{p}=0.035$.

Leaf defoliation singularly increased male inflorescence production to an average of 6.1 inflorescences at field capacity. This gives supporting evidence that the effects of complete defoliation contributed to the induction of male 
inflorescences. When complete defoliation was accompanied by a SWD of $16.8 \mathrm{~mm}$ during the second month after complete defoliation, there was an additional and significant increase in the average number of male inflorescences produced to 9.1, corresponding to an increase of $33 \%$. The additional effects of water deficit must have contributed to this increase as observed on Figure 8. This could be understood because the effects of complete defoliation carried out during the dry season was more important than when carried out during the rainy season in Ivory Coast (Durand-Gasselin et al., 1999). In this study, the specific amount of SWD needed to significantly increase male inflorescence induction in oil palm and the time range for which it is effective has been determined. In a related study, it was proven that water deficit or availability was the most determining factor in oil palm production (Nouy et al., 1996).

When soil water deficit was increased beyond $16.8 \mathrm{~mm}$ to a value of $146.2 \mathrm{~mm}$, there was a gradual fall in average male inflorescence production. This might have been due to the effects of slow cell development leading to retardation in inflorescence evocation. A similar scenario was observed in Chrysanthemum in which slow development in the capitulum of the shoot apical meristem resulted in retardation of inflorescence (Nakano et al., 2013). There was also a massive decrease in transcript abundance of cell division genes in the drought-stressed ovary of maize (Kakumanu et al., 2012).

There was a significant relationship observed between the number of male inflorescences produced and three related soil water availability variables. These variables are the amount of precipitation that was registered in the second month, the number of rainy days registered in the second month and the total amount of precipitation registered during the first two months after complete defoliation. These variables, which are environmental data collected during the second 30 days after complete defoliation gives us a clue on when the oil palm senses the impact of complete defoliation and then responses to it. The correlation coefficients presented in Table 1 do not some up to 1 because flowering in oil palm is not only influenced by environmental factors; but also by genetic factors and physiological status of the trees (Adam et al., 2005).

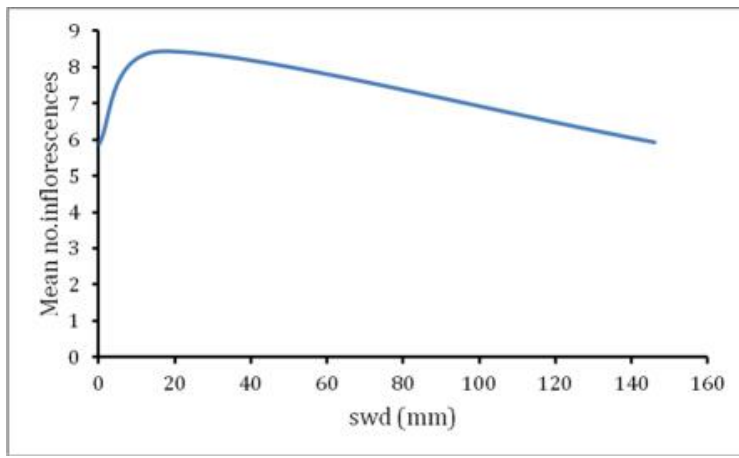

Figure 8. The effect of increasing soil water deficit on male inflorescence production. Soil water deficit (SWD) was obtained from measurements between the $30^{\text {th }}$ and

60th day after treatment of each set of trees. The

corresponding numbers of male inflorescences are represented by the vertical axis and were recorded between the 15th and 30th month after treatment. This period indicates the range of time for which the treatment is effective on the plant.

\section{Conclusion}

Complete defoliation of pisifera type of oil palm induced male flower inflorescence formation. Responses of pisifera type of oil palm to complete defoliation stress was initiated between the 30th to 60th day after defoliation. Thus response to complete defoliation stress was not immediate, but delayed until the second month after treatment. Complete defoliation was more effective in increasing male inflorescence formation when accompanied by a soil water deficit of $16.8 \mathrm{~mm}$ during the second month after treatment. The preferential induction of male flower inflorescences in pisifera type of oil palm coincide with the soluble sugar depletion in both leaves and inflorescence tissues 45 days after complete defoliation.

Complete defoliation of pisifera type of oil palm induced male flower inflorescence formation. Oil palm response to mechanical stress caused by complete defoliation was initiated between the 30th and 60th day after treatment. Thus response to stress was not immediate, but delayed until the second month after stress treatment. Complete defoliation was more effective in increasing male inflorescences when accompanied by a soil water deficit not more than $16.8 \mathrm{~mm}$ during the second month after treatment. The preferential induction of male flower inflorescences in pisifera type of oil palm coincides with the soluble sugar depletion in both leaves and inflorescence tissues 45 days after complete defoliation.

Most of the phenological processes in plants are controlled by genes, which are predominantly 
regulatory in nature. This simply means that the expression of these genes is associated to changes in environmental stimulus. Researchers wishing to undertake further studies in finding the molecular biosynthetic pathways or gene expression occurring as a result of complete defoliation stress could make use of these research findings. The finding in this paper are very important to oil palm research and crop yield forecasting because they give us sufficient information on when oil palm responses to carbon depletion and soil water deficiency.

\section{Acknowledgement}

The authors wish to acknowledge the support of the Breeding Department of CEREPAH La Dibamba Cameroon for the upkeep of the experimental blocks between 2001 and 2013. We would also like to express our gratitude to the Management of PT ASTRA Agro Lestari Ltd Indonesia for facilitating the production of this manuscript and supporting $\mathrm{PhD}$ program for WA. This work was funded by the successive Public Investment Budgets (BIP) of the Republic of Cameroon through its Ministry of Scientific Research and Innovations.

\section{Author contributions}

W. A. designed and conducted most of the experiments, analyzing the results and preparing the manuscript. M. G. assisted field activities and data collections. S. W. A. and H. V. were involved in editing the manuscript and supervising W. A.'s Ph.D. research activities. S. S. was involved in data analysis and presentation, manuscript preparation and editing. He is the major (chairman) of the supervisory committees of W. A.'s PhD. program.

\section{References}

Adam, H., S. Jouannic, J. Escoute, Y. Duval, J. L. Verdeil and J.W. Tregear. 2005. Reproductive developmental complexity in the African oil palm Elaeis guineensis, Arecaceae. Am. J. Bot. 92(11):1836-1852.

Adam, H., M. Collin, F. Richaud, T. Beule, D. Cros, A. Omore, L. Nodichao, B. Nouy and J. W. Tregear. 2011. Environmental regulation of sex determination in oil palm: current knowledge and insights from other species. Ann. Bot. 108:1529-1537.

Allen, R. G., L. S. Pereira, D. Raes and M. Smith. 1998. Crop evapotranspiration guidelines for computing crop water requirements. FAO irrigation and drainage paper no. 56. Rome.

Bikel, A. M. and D. C. Freeman. 1993. Effects of pollen vector and plant geometry on flora sex- ratio in monoecious plants. Amer. Midland Natural. 130:239-247.

Caliman, J. P. and A. Southworth. 1998. Effect of drought and haze on the performance of oil palm. International Oil Palm Congress: Commodity of the past, today and the future. IOPRI Bali, Indonesia.

Campbell, L. G., J. Luo and K. L. Mercer. 2012. Effect of water availability and genetic diversity on flowering phenology, synchrony and reproductive investment in summer squash. J. Agric. Sci. 151:775-786.

Chow, P. S. and S. M. Landhausser. 2014. A method for the routine measurement of total sugar and starch in woody plant tissues. Tree Physiol. 24:1129-1136.

Corbesier, L., P. Lejeune and G. Bernier. 1998. The role of carbohydrates in the induction of flowering in Arabidopsis thaliana: Comparison between the wild type and a starchless mutant. Planta 206:131-137.

Corley, R. H. V. 1976. Inflorescence abortion and sex differentiation, In: R. H. V. Corley, J. J. Hardon and B. J. Wood (Eds.), pp. 37-54. Development in Crop Science I: Oil Palm Research. Elsevier, Amsterdam.

Corley, R. H. V. and P. B. Tinker. 2003. Growth, flowering and yield. pp. 89-131. The Oil Palm. 4th ed. Blackwell Science Ltd., Oxford.

Cros, D., A. Flori, L. Nodichao, A. Omore and B. Nouy. 2013. Differentiated response to water balance and bunch load generates diversity of bunch production profiles among oil palm crosses (Elaeis guineensis). Tropic. Plant Biol. 6:26-36.

Durand-Gasselin, T., J. M. Noiret, R. K. Kouame, B. Cochard and B. Adon. 1999. Availability of quality pollen for improved oil palm (Elaeis guineensis Jacq.) seed production. Plant. Rech. Dev. 6:264-276.

Eastmond, P. J. and I. A. Graham. 2001. Re examining the role of the glyoxylate cycle in oilseeds. Trends Plant Sci. 6:72-78.

Flach, M. and D. L. Schuiling, 1989. Revival of an ancient starch crop: A review of the agronomy of sago palm. Agroforestry Systems 7:259-81.

Gibson, S. I. 2000. Plant sugar-response pathways: Part of a complex regulatory web. Plant Physiol. 124:1532-1539. 
Gomez-Cadenas, A., J. Mehouachi, F. R. Tadeo, E. Primo-Millo and M. Talon. 2000. Hormonal regulation of fruitlet abscission induced by carbohydrate shortage in citrus. Planta 210:636-643.

Gray, B. S. 1969. A study of the influence of genetic, agronomic and environmental factors on the growth and bunch production of the oil palm on the west coast of West Malaysia. Ph.D thesis, University of Aberdeen. p. 947.

Hardon, J. J. and R. H. V. Corley. 1976. Pollination. In: R. H. V.Corley, J. J. Hardon and B. J. Woods (Eds.). Oil Palm Research. Elsevier Scientific Pub. Co., Amsterdam. pp. 300-305.

Hartley, C. W. S., 1988. The oil palm (Elaeis guineensis Jacq.). Third Edition. Longman, Tropical Agriculture Series, London, UK, p. 761.

Hartwig, T., G. S. Chuck, S. Fujioka, A. Klempien, R. Weizbauer, D. P. V. Potluri, S. Choe, G. S. Johal and B. Schulz. 2011. Brassinosteroid control of sex determination in maize. Proc. Natl. Acad. Sci. USA, 108(49) doi: 10.1073/pnas.1108359108.

Henson, I. E., K. C. Chang, M. Siti Nor Aishah, S. H. Chai, M. Y. Hasnuddin and A. Zakaria. 1999. The oil palm trunk as a carbohydrate reserve. J. Oil Palm Res. 11(2):98-113.

Kakumanu, A., M. M. R. Ambavaram, C. Klumas, A. Krishan, U. Batlang, E. Myers, R. Grene and A. Pereira. 2012. Effects of drought on gene expression in maize reproductive and leaf meristem tissue revealed by RNA-seq. Plant Physiol. 160:846-867.

Killmann, W. and S. C. Lim. 1987. Anatomy and properties of oil palm stem. In: Proc. of the National Symposium on Oil Palm By-products for Agro-based Industries. PORIM, pp. 18-42.

King, R. W. and L. T. Evans. 1991. Shoot apex sugars in relation to long day induction of flowering in Lolium temulentum L. Aust. J. Plant Physiol. 18:121-135.

Koch, K. E. 1996. Carbohydrate modulated gene expression in plants. Annu. Rev. Plant Physiol. Plant Mol. Biol. 47:509-540.

Koch, K. E. and Y. Zeng. 2002. Molecular approaches to altered C-partitioning: Genes for sucrose metabolism. J. Amer. Soc. Hort. Sci. 127:474-483.
Lee, J. M., P. Satish, D. J. Donaghy and J. R. Roche. 2010. Plants modify biological process to ensure survival following carbon depletion: A Lolium perenne model. PLoS ONE 5(8): e12306. Doi: 10.1371/ journal.pone.0012306.

Legros, S., I. Mialet-Serra and J. P. Caliman. 2006. Carbohydrates reserves in 9-year-old oil palm: nature, distribution and seasonal changes. Optimum use of resources: challenges and opportunities for sustainable oil palm development. IOPC Bali.

Legros, S., I. Mialet-Serra, J. P. Caliman, F. A. Siregar, A. Clement-Vidal, D. Fabre and M. Dingkuhn. 2009. Phenology, growth and physiological adjustments of oil palm (Elaeis guineensis Jacq) to sink limitation induced by fruit pruning. Ann Bot. 104(6):1183-1194.

Liu, Y. H., C. E. Offler and Y. L. Ruan. 2013. Regulation of fruit and seed response to heat and drought by sugars as nutrients and signals. Front. Plant Sci. 4:282.

Lopez-Molina, L., S. Mongrand and N. H. Chua. 2001. A post germination developmental arrest checkpoint is mediated by abscisic acid and requires the ABI5 transcription factor in Arabidopsis. Proc. Natl. Acad. Sci. USA. 98:4782-4787.

Mialet-Sera, I., A. Clement-Vidal, O. Rouspard, C. Jourdan and M. Dingkuhn. 2008. Whole plants adjustments in coconuts (Cocos nucifera) in response to source-sink imbalance. Tree Physiol. 28:1199-1209.

Nakano, Y., Y. Higuchi, K. Sumitomo and T. Hisamatsu. 2013. Flowering retardation by high temperature in chrysanthemums: Involvement of FLOWERING LOCUS T-like 3 gene repression. J. Exp. Bot. 64(4):909-920.

Nouy, B., A. Omore and F. Potier. 1996. Oil palm production cycles in different ecologies: Consequences for breeding. In: D. Arifin, et al. (Eds.). International Palm Oil Congress, Competitiveness for the 21st Century. PORIM Kuala Lumpur, Malaysia, pp. 62-75.

Nouy, B., L. Baudouin, N. Djegui and A. Omore. 1999. Oil palm under limiting water supply conditions. Plant. Rech. Dev. 6:31-45.

Ohto, M., K. Onai, Y. Furukawa, E. Aoki, T. Araki and K. Nakamura. 2001. Effects of sugar on vegetative development and floral transition in Arabidopsis. Plant Physiol. 127:252-261. 
Pien, S., J. Wyrzykowska and A. J. Fleming. 2001. Novel marker genes for early leaf development indicate spatial regulation of carbohydrate metabolism within the apical meristem. Plant J. 25:663-674.

Rolland, F., B. Moore and J. Sheen. 2002. Sugar sensing and signaling in plants. Plant Cell 14:S185-S205.

Roldan, M., C. Gomez-Mena, L. Ruiz-Garcia, J. Salinas and J. M. Martinez-Zapater. 1999. Sucrose availability on the aerial part of the plant promotes morphogenesis and flowering of Arabidopsis in the dark. Plant J. 20:581590.
Sheen, J., L. Zhou and J. C. Jang. 1999. Sugars as signaling molecules. Curr. Opin. Plant Biol. 2:410-418.

Silpi, U, A. Lacointe and P. Kasempsap. 2007. Carbohydrate reserves as competing sink: evidence from tapping rubber trees. Tree Physiol. 27:881-889.

Smeekens, S. 2000. Sugar-induced signal transduction in plants. Annu. Rev. Plant Physiol. Plant Mol. Biol. 51:49-81.

Spalik, K. 1991. On evolution of andromonoecy and overproduction of flowers - a resource allocation model. Biol. J. Lin. Soc. 42:325336. 